\title{
Can Local Ecological Knowledge Contribute to Wildlife Management? Case Studies of Migratory Birds
}

\author{
Grant Gilchrist, Mark Mallory, and Flemming Merkel
}

\begin{abstract}
Sound management of wildlife species, particularly those that are harvested, requires extensive information on their natural history and demography. For many global wildlife populations, however, insufficient scientific information exists, and alternative data sources may need to be considered in management decisions. In some circumstances, local ecological knowledge (LEK) can serve as a useful, complementary data source, and may be particularly valuable when managing wildlife populations that occur in remote locations inhabited by indigenous peoples. Although several published papers discuss the general benefits of LEK, few attempt to examine the reliability of information generated through this approach. We review four case studies of marine birds in which we gathered LEK for each species and then compared this information to empirical data derived from independent scientific studies of the same populations. We then discuss how we attempted to integrate LEK into our own conservation and management efforts of these bird species with variable success. Although LEK proved to be a useful source of information for three of four species, we conclude that management decisions based primarily on LEK, in the absence of scientific scrutiny, should be treated with caution.
\end{abstract}

Key Words: Arctic; Inuit; LEK; local ecological knowledge; marine birds; population declines; TEK; traditional ecological knowledge

\section{INTRODUCTION}

Effective and sustainable management of wildlife populations requires quantitative information on rates of sex-specific harvest, survival, and reproduction, as well as data on population size, movement patterns, and relationships to habitat, to ensure that harvest does not jeopardize the survival of populations (Lebreton et al. 1992, Ludwig et al. 1993). For many global wildlife populations, however, technical (scientific) information required for sustainable management is insufficient. In these cases, possible alternative sources of information regarding populations and their habitats should be sought out, evaluated, and integrated into management decisions. For any of these approaches, however, the key element is data reliability: poor data may lead to inaccurate interpretations and flawed decision making (Walters and Hilborn 1978, Ludwig et al. 1993).

There has been growing international recognition that traditional and local ecological knowledge (we will further define both) can be useful sources of information to complement "western scientific approaches" to resource management (e.g., Chemilinsky 1991, Berkes et al. 2000). Because it is typically derived from people who have lived, hunted, and trapped wildlife, its role in wildlife management is analogous to "expert opinion" used in population modeling (e.g., Walters and Holling 1990, Zabel et al. 2002). Ecological knowledge has been applied to diverse scientific disciplines (Gadgil et al. 1993, Johannes 1998, Krupnik and Jolly 2002), and it may be particularly useful when managing wildlife populations that occur in remote locations where extensive scientific studies may be impractical (Barsh 1997, Ferguson et al. 1998). Despite this, local ecological knowledge has been received skeptically by wildlife managers and conservation biologists. This is evidenced by the lack of peer-reviewed articles that incorporate it within the biological literature (Nadasdy 2003). Therefore, we concur with Huntington et al. (2004) that "traditional ecological knowledge and science combined has not realized its potential." 
Most "Local Ecological Knowledge" (LEK) studies of wildlife are qualitative. Consequently, LEK is rarely integrated into wildlife management decision making, a discipline that historically has relied on quantitative results derived through accepted scientific methods (Mauro and Hardison 2000). There is a need to carefully compare specific observations from LEK with those from science, because they reflect independent sources of information that could corroborate each other. Such a comparison could also increase confidence and depth of knowledge in both approaches (Huntington et al. 2004). However, this comparative approach is difficult to achieve in practice, because LEK and scientific understanding are usually gathered from different locations, time periods, and wildlife populations (Huntington et al. 2004).

To our knowledge, no one has been in a position to compare and contrast ecological knowledge across species that vary in their ecology and degree of harvest, nor has anyone compared ecological knowledge with empirical scientific data of the same populations, during the same time periods. To do so could help to identify: (1) constraints and limitations of both approaches if they exist; (2) gaps of information that might be predictable (e.g., during seasons when species are not harvested); and (3) topics in which both LEK and scientific study could contribute information required for wildlife management and conservation (e.g., population distribution and trends).

As biologists studying migratory birds in the northwestern Atlantic and Arctic Oceans, we wanted to integrate LEK of the Inuit, the indigenous people of Arctic Canada and Greenland, into management of bird species. We compared LEK and scientific information derived from the same bird populations. We anticipated that LEK would help to identify new ideas that warranted further investigation, detect changes in population size and/ or distribution that otherwise would have gone undetected by western science, and identify potential mechanisms that could explain observed changes in bird populations. Here, we describe four case studies in which we have incorporated LEK into the conservation and management of four Arctic marine bird species.

\section{DEFINITIONS AND CONCEPTS}

A recurring challenge when discussing ecological knowledge, and convincing the scientific community of its merits, is to define exactly what it is (Huntington 2000). The term is generally synonymous with "oral tradition," "indigenous knowledge," "local or community knowledge," or "traditional ecological knowledge" (Johannes 1989). It has been defined in many ways (e.g., Duerden and Kuhn 1998, Pierotti and Wildcat 2000), but can be summarized as "a cumulative body of knowledge, practice, and belief, evolving by adaptive processes and handed down through generations by cultural transmission. [It concerns] the relationship of living beings (including humans) with one another and with their environment" (Berkes et al. 2000:1252). Traditional ecological knowledge (TEK) is the knowledge and insight acquired through extensive observation of an area or species (Huntington 2000), and it is therefore not restricted to indigenous peoples alone. For example, although we present the ecological knowledge of Canadian Inuit in the case studies to be discussed, we acknowledge that similar ecological information also exists for these marine birds among nonaboriginal people living in Newfoundland and Labrador, Canada (Chaffey 2003), and Iceland (Jonsson 2001).

Even strong proponents of TEK acknowledge that "although the value of TEK in scientific research, impact assessment and conservation monitoring has become more apparent and accepted, wider application of TEK-derived information remains elusive" (Huntington 2000). Perhaps those being asked to implement ecological knowledge are confused by the vague terminology used to describe a variety of approaches and the types of information derived from them (Nadasdy 1999). Although TEK is the most commonly used term in the literature, it may not be the most appropriate to describe the information actually presented in many recent studies (including our own). The word "traditional" intentionally emphasizes historical content that is "handed down through generations by cultural transmission", typically incorporating anecdotes and oral tradition of a people over many generations. However, we stress that, in a practical sense, for wildlife management, the type of ecological knowledge often gathered through interviews is "current local knowledge" acquired more recently over the lifetime of individuals, unless the study explicitly seeks out long-term, historical information 
as its objective (e.g., Ferguson et al. 1998). Consequently, we conclude that the term LEK best describes the information considered in our case studies because it was based on the observations of individuals during their lifetimes and, to varying degrees, was interspersed with some historical information provided by their older relatives.

\section{EVALUATING INUIT LOCAL ECOLOGICAL KNOWLEDGE: CASE STUDIES}

Local ecological knowledge studies in the Arctic have focused primarily on harvested species such as caribou (Ferguson et al. 1998), polar bears (Van de Velde et al. 2003), and whales (Hay 2000). The Canadian and Greenland Arctic also support globally important populations of marine birds, including sea ducks and pelagic seabirds (Gaston and Jones 1998). We recently gathered LEK on four marine bird species (see Fig. 1), following the methods of Nakashima and Murray (1988) and Hay (2000). Most structured interviews were conducted individually, and all in the native language of the eastern Arctic (Inuktitut), with a set questionnaire and maps, but with the opportunity for the interviewees to elaborate on questions as they saw fit. Note that the interviewees typically indicated that they "did not know" if they could not answer a question, and would rarely speculate on matters. In some cases, group interviews following the semidirective method were used (Nakashima and Murray 1988), in which issues were discussed more informally and the information was recorded.

The species included: Common Eider Duck (Somateria mollissima sedentaria), Harlequin Duck (Histrionicus histrionicus), Ivory Gull (Pagophila eburnea), and Thick-billed Murre (Uria lomvia). In the eastern Canadian Arctic and west Greenland, these species differ in several important aspects of their ecology and in their degree of harvest. We assumed that this would influence the amount and diversity of LEK existing for them. We will briefly review the LEK that we gathered for each species, and will compare it to empirical data derived from independent scientific studies of the same populations. Importantly, we will also discuss our attempts to incorporate LEK information into the harvest management, monitoring, and conservation of these marine bird species. Although this may be a controversial undertaking, we feel that this step is required to integrate both LEK and scientific approaches into wildlife management and conservation, something that is strongly advocated (Gadgil et al. 1993, Berkes et al. 2000), but rarely attempted.

\section{Common Eider Duck}

The Common Eider (Somateria mollissima sedentaria) is a large, marine duck that typically nests in colonies on small Arctic islands. In Hudson Bay, Nunavut, Canada, Common Eider ducks do not migrate, but overwinter in polynyas (i.e., permanent areas of open water surrounded by ice) and along ice edges near the Belcher Islands (Gilchrist and Robertson 2000). In the mid 1990s, Inuit from the community of Sanikiluaq reported that the regional eider population had recently declined. In response, biologists and local Inuit repeated surveys of islands that had been conducted during 1985-1989, and found that eider populations had indeed declined by $75 \%$ since that time (Robertson and Gilchrist 1998). Inuit stated that extensive sea ice during the winter of 1991-1992 had limited the locations where eiders could feed in open water, and that this had resulted in their mass starvation. Although the ultimate cause of the severe winter ice conditions was unknown to them (i.e., the Pinatubo volcanic eruption in the southern hemisphere, which lowered circumpolar temperatures; Ganter and Boyd 2000), local Inuit correctly detected both a change of sea ice conditions and the mass die-off of eiders that resulted (Robertson and Gilchrist 1998). Without their LEK, this dramatic population decline would have gone undetected by western science.

Furthermore, recent field research during winter has confirmed several aspects of Common Eider ecology that were first presented to us by Inuit through LEK interviews (Gilchrist and Robertson 2000): the population has increased since the mortality event in 1992, when the population declined; harvest of eiders by Inuit is greatest in the fall; and there is age-specific habitat use in winter (i.e., juvenile eiders are more likely to overwinter in polynyas without ever traveling to leads in the pack ice to feed). Inuit also correctly related that eider ducks residing in polynyas cannot forage for several hours each day because strong tidal currents prevent them from reaching mussels on the sea floor. Although Inuit did not know the exact current velocity that constrained the ducks $(4 \mathrm{~m} / \mathrm{sec}$ when 
Fig. 1. A map illustrating locations of study.

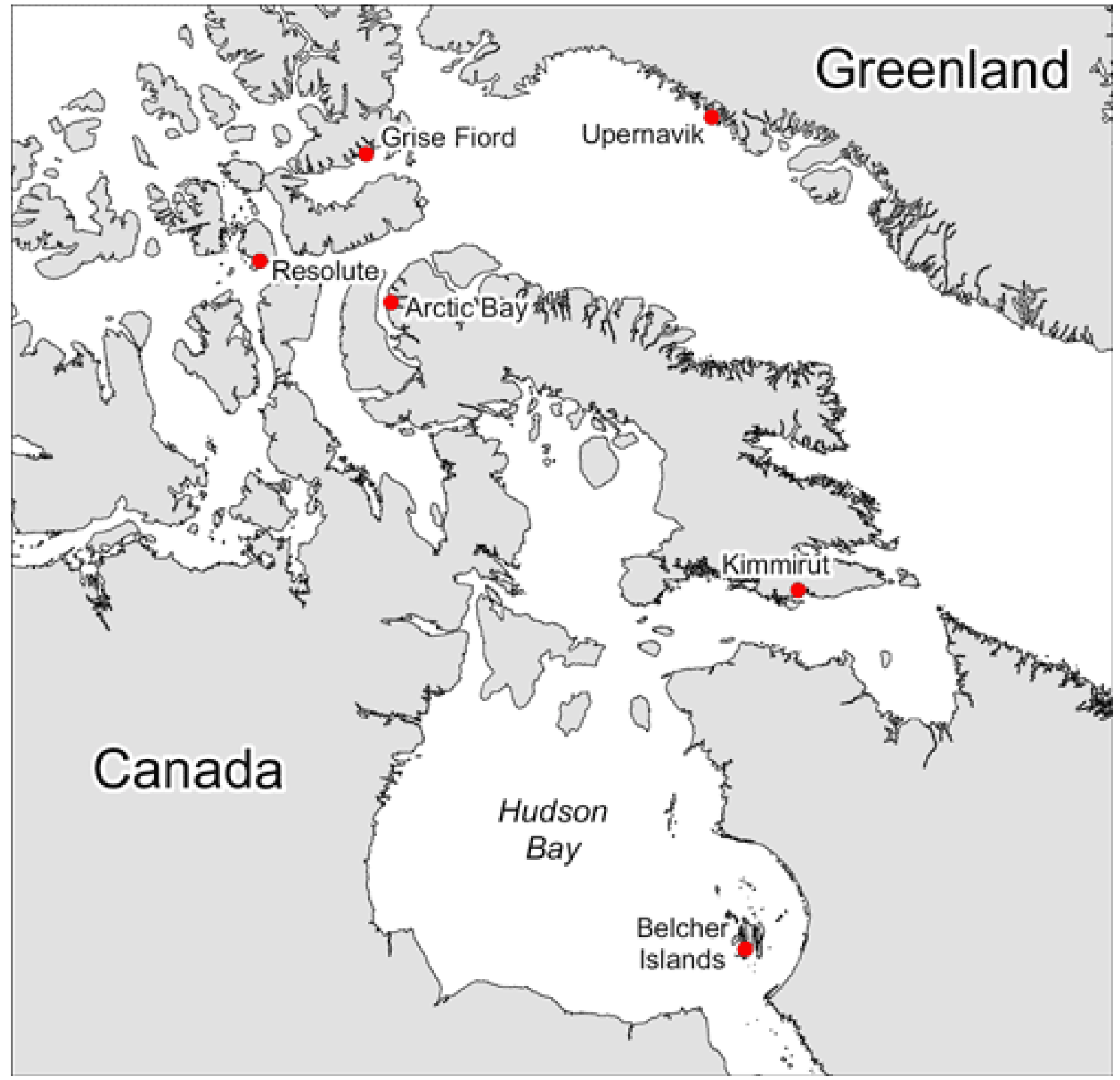

diving in $10 \mathrm{~m}$ of water), their comments directed us to quantify this important environmental parameter, which otherwise would have been overlooked. This LEK information is now being incorporated into management plans for eiders.
Specifically, Inuit LEK identified the most important polynyas for wintering eiders, and these locations are now identified as sites worthy of formal protection under the Marine Wildlife Areas Program of the Canadian Wildlife Service (Mallory 
and Fontaine 2004). Further, as part of eiderdown feather collection activities on nesting islands, the community of Sanikiluaq is monitoring the eider breeding population annually in collaboration with the Canadian Wildlife Service.

LEK described the Hudson Bay eider diet, agespecific habitat use, winter mortality in 1992, and the environmental factors constraining eider foraging, all of which agreed with recent scientific results. This indicates that local Inuit have extensive and accurate knowledge of this population. This level of accuracy may reflect that eiders are nonmigratory, they are harvested throughout the year, and that local hunters frequently travel to areas that support eider ducks, even in winter.

\section{Harlequin Duck}

The eastern Harlequin Duck (Histrionicus histrionicus), is a rare, small duck that frequents fast-flowing streams and coastal inlets of eastern North America. It was previously known to occur on Baffin Island, Nunavut, Canada (Soper 1946, Robertson and Goudie 1999), but had not been observed there by scientists since the 1930s, despite some surveys in the region. We conducted LEK interviews of Inuit hunters in four communities around southern Baffin Island to gather data on this rare species (Mallory et al. 2003a). Inuit immediately recognized this duck and stated that it still occurred in this area, although in low numbers. The specific coastlines and rivers where the species was reported directly overlapped with those previously identified by Soper (1946). Also, Inuit correctly identified aspects of this species' biology, including preferred habitats (fast-flowing streams and rapids areas) and seasonal movements (floe edge and stream use in the spring and summer, with movements of adults and young to fresh/saltwater interfaces in the fall; Robertson and Goudie 1999).

Subsequent ground surveys for Harlequin Ducks found three individuals at one river in this region over two field seasons, indicating that scientific surveys for monitoring distribution were not cost effective for Harlequin Ducks in this remote area. In this case, LEK is the most appropriate method to monitor the occurrence and distribution of the Harlequin Duck population on south Baffin Island. Inuit travel to these areas routinely by boat, and a long-term, community-based monitoring program has been initiated. Color posters in both Inuktitut and English have been posted in communities, and people are encouraged to voluntarily report their observations of Harlequin ducks. Hence, the information is anecdotal, in large part because this is not a species harvested by Inuit and there is little interest in embarking on dedicated boating trips to locate them (Mallory et al. 2003a).

In contrast to Baffin Island, Canada, a previously undocumented moulting population of Harlequin Ducks was recently discovered when ducks implanted with satellite transmitters in Labrador, Canada, migrated to the south coast of west Greenland. Before this discovery, both researchers and local Inuit residents in south Greenland were unaware that Harlequins moulted there. This could reflect that Harlequin Ducks are not hunted in Greenland and occur along remote coastlines that are now rarely visited. The coastline of Greenland was subsequently surveyed by air in 1999, and distribution of moulting Harlequin Ducks in Greenland is now well described (Boertmann and Mosbech 2002).

These findings illustrate that, for Harlequin Ducks breeding in the eastern Canadian Arctic and Greenland, LEK concerning population size, breeding locations, and moulting sites differed considerably between communities and regions. This is understandable, given both the rarity and secretive nature of this species in the Arctic.

\section{Ivory Gull}

In Canada, the Ivory Gull (Pagophila eburnea) breeds in remote locations on Ellesmere, Devon, Seymour, and northwestern Baffin Islands, Nunavut (MacDonald and Macpherson 1962, Haney and MacDonald 1995), and winters offshore near the southern edge of pack ice between Canada and Greenland (Orr and Parsons 1982). Inuit residents of three Arctic communities reported to the Canadian Wildlife Service that they observed fewer Ivory Gulls than in the past. To address these community concerns, we visited the community of Arctic Bay and conducted detailed interviews of 12 hunters to assess their knowledge of Ivory Gull habits and population trends (Mallory et al. 2003b). Interestingly, LEK from Arctic Bay had first alerted scientists to the presence of previously unknown Ivory Gull colonies on the Brodeur Peninsula, northwest Baffin Island, in the 1930s (Bray 1943). 
Results from our interviews showed that opinions within the community of Arctic Bay were mixed, with respect to both abundance and distribution of Ivory Gulls. Half of the interviewees said that they saw fewer gulls now than in the past, while one person stated that he saw more gulls now. Some said that the birds had moved elsewhere. There was consensus on the coarse timing at which gulls could be observed (i.e., spring and fall migration), but no one from the community had been to an Ivory Gull colony in their lifetime. Thus, even a relative assessment of the change in the regional breeding population was questionable, and absolute measures were impossible to obtain.

Shorter, informal interviews with four Inuit from Grise Fiord, 13 from Resolute Bay, and 10 from Pond Inlet, Nunavut, in contrast, provided more consistent reports of Ivory Gull declines (Mallory et al. 2003b; M. J. Mallory and H. G. Gilchrist, unpublished data). Because most residents of these communities observed Ivory Gulls regularly at community garbage dumps or marine mammal carcasses left nearby on the sea ice, the decline in gulls was obvious to them (Mallory et al. 2003b). Subsequent aerial surveys of breeding colonies by us confirmed that Ivory Gulls at in the Canadian Arctic had indeed declined by $85 \%$ since the early 1980s (Gilchrist and Mallory 2005). Thus, collectively, Inuit of the High Arctic were correct in their notion of gull declines based upon their longterm observations of gulls during spring and fall migration (Mallory et al. 2003b), and their expressed concerns prompted the aerial surveys required to quantify the rate of decline. Collectively, these results have prompted the reevaluation of the Ivory Gull under the Canadian Endangered Species Act (Stenhouse et al. 2004).

Nonetheless, we recognize that the LEK information we first gathered at Arctic Bay was inconsistent among interviewees, and would have provided little usable information on which to base management decisions in the absence of corroborating survey data. This may be partly explained because people in Arctic Bay apparently have little direct experience with Ivory Gulls. The information that they provided may be more speculative or variable, especially if it is based on a few observations, which would be susceptible to bias. It remains unknown what factors have been responsible for Ivory Gull declines, but harvest of adults in Greenland and climate-induced changes in the wintering grounds are probable factors
(Gilchrist and Mallory 2005). Neither of these could be determined by residents of High-Arctic communities.

\section{Thick-billed Murre}

The Thick-billed Murre (Uria lomvia) is a pelagic seabird that breeds in dense colonies on exposed cliff ledges. In the Canadian Arctic, adult murres are occasionally harvested by Inuit during the breeding season. In contrast, murres in western Greenland were harvested in both winter and summer until 2002 (Christensen 2001). In the Upernavik Region of west Greenland, murres are only present between May and September when the ocean is largely ice-free. Thus, most harvest in Upernavik historically has occurred during the breeding season (Falk and Durinck 1992), and colonies have declined dramatically since 1965 , when commercial exploitation of murres began there. Between 1965 and 1975, at least 92000 murres were reportedly shot at colonies, packaged at a nearby community fish plant, and distributed for sale throughout Greenland (Kampp et al. 1994, Hansen 2002).

In 1993, we conducted interviews among 10 hunters in the community of Upernavik. We asked whether the size of local murre colonies had declined, and if so, what had caused these declines. All of the hunters responded that both the number of murres at sea and nesting at colonies in the region had declined in recent decades. Two of 10 hunters cited overhunting as the cause, and that too many adult murres were being shot in summer. The remaining interviewees concluded that frequent disturbance caused by shooting at the colonies had "upset the birds" and prompted them to move elsewhere to breed. This implied that the population had not declined per se, but that murres had simply moved to nest elsewhere, although hunters could not identify locations of newly established colonies. Recent aerial and boat surveys of the entire west coast of Greenland confirm that no new colonies have been initiated (Boertmann et al. 1996), and murre populations continue to decline in the Upernavik region (Merkel et al. 1999).

At 10 community meetings held at Upernavik district settlements in 1998 and 1999, all participants agreed that the murre colonies in southern Upernavik had declined in numbers, and generally gave the same reasons for the decline as 
reported previously in 1993. However, they also argued that murre hunting during winter in southwest Greenland was to blame (Slettemark and Christensen 1999). It should be noted that the numerical contribution of Upernavik murres to the harvest in southwest Greenland is small (Falk and Durinck 1992), because most murres wintering in southwest Greenland originate from other circumpolar countries (Kampp 1988). Consequently, the contribution of the winter harvest of murres from the Upernavik region is small when compared to the numbers of murres shot directly at the colonies in summer (Kampp 1988). Thus, regional harvest has far greater direct impact on the regional breeding population than does the winter harvest in southwest Greenland, and this was not considered by local residents.

In this case, not only has LEK not contributed to regional conservation of a harvested species, but continuing misconceptions held by many local residents may actually be contributing to its unsustainable harvest (Gilchrist 1999). These misconceptions, which were identified only through the collection of LEK, identified the need to establish an education program for local residents which described the natural history and population demography of Thick-billed Murres both locally in Greenland, and throughout the North Atlantic. This program is now ongoing, and will be fundamental to the conservation of this regional murre population.

\section{Conclusions drawn from case studies}

What lessons have we learned from these four examples? First, it is clear that we obtained LEK relevant to the conservation and management of the bird species in which we were interested, and for which we had limited existing information (Table 1). In two cases, dramatic population declines were reported that had previously gone undetected by western science. Second, the breadth and quality of LEK varied among species, and thus the relationship of the species in question to the local community must be clearly understood. Third, the accuracy of LEK often varied among interviewees, so an adequate sample size of individuals must be questioned to increase confidence in the information provided. Fourth, LEK quality was higher for species with which local peoples had greater familiarity through harvest or year-round contact, or both (e.g., nonmigratory eiders). However, this may not necessarily be related to levels of harvest alone (e.g., breeding murres in Greenland). Finally, quantitative LEK information may be available for the timing of movements and distributions of species, but generally lacks the necessary detail for tracking population change, except for catastrophic declines (e.g., $>75 \%$ population change; see previous examples).

\section{DISCUSSION}

\section{What is needed?}

In its current form, approaches to collecting LEK vary dramatically among studies and species. A standardized approach to collection will help with the integration and interpretation of ecological knowledge. At a minimum, this approach should include interviews of several individuals separately to quantify variability among interviewees, as well as questions to assess each individual's (and community's) familiarity and experience with the habitat and species in question (i.e., their level of expertise). Depending on the time and financial constraints of the study, a targeted (nonrandom) a priori selection of the individuals most knowledgeable about the species in question is also advisable. We also recommend that authors should distinguish between traditional ecological knowledge (TEK) and local ecological knowledge (LEK) during a study to recognize that the degree of longterm, historical information can vary among individuals, communities, and the species studied.

Most LEK is inherently qualitative and difficult to validate. Therefore it could help to identify coarse (and necessarily large) changes in population size or distribution (e.g., declines of eiders and gulls), but our experience suggests that scientific surveys will almost always be required to verify and measure population changes at the levels necessary for wildlife management. Also, although LEK may be available for a species (e.g., natural history of Ivory Gulls), it may be irrelevant or of insufficient quality to provide information useful to wildlife management. The same can be said of many scientific research studies (Ford 2000). Finally, we must acknowledge that LEK may be incorrect. For example, those being interviewed may not understand the full life cycle of a species (e.g., murres in Greenland), or recognize that the conditions on which their LEK is based have changed (Krupnik and Jolly 2002). What is needed 
Table 1. Summary of LEK information provided in relation to degree of community contact with a species.

\begin{tabular}{lcccc}
\hline \hline Case study & $\begin{array}{c}\text { Degree of community } \\
\text { contact with species }\end{array}$ & $\begin{array}{c}\text { Occurrence of } \\
\text { species }\end{array}$ & $\begin{array}{c}\text { Relationship with } \\
\text { species }\end{array}$ & $\begin{array}{c}\text { Accuracy of LEK } \\
\text { information }\end{array}$ \\
\hline Common Eider Duck & very high & common & harvested year round & very high \\
Harlequin Duck & very low & rare & not harvested & not harvested \\
Ivory Gull & low & rare & harvested seasonally & low \\
Thick-billed Murre & high & common & hate & \\
\hline
\end{tabular}

${ }^{a}$ Categories: very high, correct information on population trend, distribution, and ecological information explaining trends; high, correct information on population trend and distribution of a species; moderate, correct information on geographic distribution of species; low, incorrect information on population trend and/or distribution.

is to conduct studies that rigorously attempt to identify why this may be the case. Not to do so helps to justify the existing skepticism that LEK is an unreliable source of information.

It also may be possible to test the accuracy of LEK. For example, how might travel distance away from a community influence the quality of LEK regarding the distribution and abundance of a species? We predict that the quality of LEK should decline with increasing distance from both communities and travel routes, because remote locations that are rarely visited should be more poorly known than locations nearby. Although this prediction appears to be intuitive and self-evident, to our knowledge, it has never been tested explicitly. It also has important implications for managing wildlife at different geographic and temporal scales (Nakashima and Murray 1988, Ferguson et al. 1998). This prediction could be tested by statistically comparing LEK to rigorous survey data, perhaps using nonparametric, categorical approaches.

\section{CONCLUSIONS}

The application of TEK and LEK as a tool for wildlife and habitat management continues to be debated (Mauro and Hardison 2000). Ecological knowledge is still received with skepticism by much of the scientific community (Pierotti and Wildcat 2000), perhaps explaining its infrequent appearance in peer-reviewed wildlife journals. This skepticism stems from the fact that LEK takes many forms across cultures and scientific disciplines; it often mixes policy or perspectives on resource management with actual data collection; and it is nearly always qualitative in nature (Berkes et al. 2001). Importantly, it is rarely compared to other sources of information (but see Huntington et al. 2004). As well, the historical and current approaches of indigenous peoples to management of wildlife and their habitats have not been tested, nor are these approaches always in the interest of conservation (Gadgil and Berkes 1991, Krech 1999, Hansen 2002). Perhaps more importantly, LEK studies often do not follow the accepted hypothetico-deducto approach of the scientific method (Gunn et al. 1988), nor have many studies undergone independent and blind repetition of inquiry. Despite these limitations, there is growing evidence that ecological knowledge can and should play an important role in wildlife conservation, particularly in remote areas where standard scientific approaches may be impractical (Gunn et al. 1988, Johannes 1998). Based on the success of the case studies just presented (Table 1), we strongly support this view and advocate its use in studies of wildlife management and conservation biology. As stated by Wilhere (2002:28), "most conservation dilemmas are enmeshed in considerable scientific uncertainty ... we must strive to reduce it." Local ecological knowledge affords one means by which this can be done.

Aside from providing important indicators that help to direct scientific investigation, LEK is an important tool to help develop policies on wildlife research that incorporate cultural values (Gunn et al. 1988). Our experience has shown that gathering 
LEK helps to engage local stakeholders as part of a team addressing a shared conservation concern, an approach generally more productive than scientific studies alone (Zabel et al. 2002). For example, although the LEK that suggested that emigration of murres could explain regional population declines was incorrect, it highlighted the need to establish a regional education program.

Increasingly, governments and funding agencies in the circumpolar Arctic (Gunn et al. 1988, Rydahl and Egede 1999) and around the world (UNEP 1992) are expecting LEK to be used in the management of wildlife. In the case of these marine bird species, we have shown that LEK can be a useful companion to standard scientific approaches. In other cases, we acknowledge that LEK can be incorrect. Although higher quality LEK is usually available for harvested species (e.g., Ferguson et al. 1998), this may not always be the case (e.g., murres). Management decisions based primarily on LEK, in the absence of scientific scrutiny, could prove potentially damaging to wildlife populations. In Greenland, for example, management of murre harvest based on the LEK notion that colonies had moved (rather than the scientific evidence of an overall decline in the population) is apparently contributing to further population declines, and perhaps to unfair harvest restrictions on hunters in other regions.

We strongly advocate the use of local ecological knowledge in efforts to manage and conserve wildlife, but caution that rigorous testing of LEK is necessary prior to its incorporation into management plans. This testing needs to address variability in LEK among individuals, within and among communities, and also across species. Thus, we suggest that LEK must undergo the same rigorous testing as the other sources of information alongside which it will be used. This will potentially have the added benefit of raising the standard and credibility of LEK. Such a process will be necessary to meet government and community goals of habitat protection and reliable harvest management in the face of cultural and environmental change (Gadgil et al. 1993).

Responses to this article can be read online at: http://www.ecologyandsociety.org/vollo/iss 1/art20/responses/

\section{Acknowledgments:}

We thank the Canadian Wildlife Service, Greenland Institute of Natural Resources, Polar Continental Shelf Project, and Nunavut Wildlife Management Board for supporting the field research through which we generated many of our ideas. We also benefited from discussions with J. Akearok, L. Arragutainaq, A. Fontaine, S. Gilliland, S. Han, K. McCormick, S. Stach Nielsen, Z. Novalinga, G. Robertson, F. Sejersen, I. Stirling, and M. Wheatley. We thank K. McCormick, I. Stirling, G. Robertson, S. Gilliland, R. Knight, and anonymous referees for commenting on earlier drafts of this manuscript. Finally, we thank the many Inuit throughout northern Canada and Greenland who contributed greatly to our understanding of the Arctic through their local knowledge and direct participation in marine bird research.

\section{LITERATURE CITED}

Barsh, R. L. 1997. Forests, indigenous people, and biodiversity. Global Biodiversity 7:20-23.

Berkes, F., J. Colding, and C. Folke. 2000. Rediscovery of traditional ecological knowledge as adaptive management. Ecological Applications 10: $1251-1262$.

Berkes, F., J. Mathias, M. Kislalioglu, and $\mathbf{H}$. Fast. 2001. The Canadian Arctic and the Oceans Act: the development of participatory environmental research and management. Ocean and Coastal Management 44:451-469.

Boertmann D., and A. Mosbech. 2002. Molting Harlequin Ducks in Greenland. Waterbirds 25:326-332

Boertmann, D., A. Mosbech, K. Falk, and K. Kampp. 1996. Seabird colonies in western Greenland. National Environmental Research Institute Technical Report Number 170. National Environmental Research Institute, Copenhagen, Denmark.

Bray, R. 1943. Notes on the birds of Southampton Island, Baffin Island and Melville Peninsula (with 
comments by T. H. Manning). Auk 60:504-536.

Chaffey, H. 2003. Integrating scientific knowledge and local ecological knowledge (LEK) about common eiders in southern Labrador, Canada. Thesis. Memorial University of Newfoundland, St. John's, Newfoundland, Canada.

Chemilinsky, E. 1991. On social science's contribution to government decision making. Science 254:226-231.

Christensen, T. 2001. Seabird harvest in Greenland. Pages 22-37 in L. Denlinger and K. Wohl, editors. Seabird harvest regimes in the circumpolar nations. Circumpolar Seabird Working Group Technical Report Number 9. CSWG, Reykjavik, Iceland.

Duerden, F., and R. G. Kuhn. 1998. Scale, context, and application of traditional knowledge of the Canadian north. Polar Record 34:31-38.

Falk, K., and J. Durinck. 1992. Thick-billed murre hunting in west Greenland. Arctic 45:167-178.

Ferguson, M., A. D., R. G. Williamson, and F. Messier. 1998. Inuit knowledge of long-term changes in a population of arctic tundra caribou. Arctic 51:201-219.

Ford, E. D. 2000. Scientific method for ecological research. Cambridge University Press, Cambridge, UK.

Gadgil, M., and F. Berkes. 1991. Traditional resources management systems. Resource Management and Optimization 8:127-141.

Gadgil, M., F. Berkes, and C. Folke. 1993. Indigenous knowledge for biodiversity conservation. Ambio 22:151-156.

Ganter, B., and H. Boyd. 2000. A tropical volcano, high predation pressure, and the breeding biology of arctic waterbirds: a circumpolar review of breeding failure in the summer of 1992. Arctic 53:289-305.

Gilchrist, H. G. 1999. Declining thick-billed murre Uria lomvia colonies experience higher gull predation rates: an inter-colony comparison. Biological Conservation 87:21-29.
Gilchrist, H. G., and M.J. Mallory.2005. Declines in abundance and distribution of the Ivory Gull (Pagophila eburnea) in Arctic Canada. Biological Conservation 121:303-309.

Gilchrist, H. G., and G. J. Robertson. 2000. Observations of marine birds and mammals wintering at polynyas and ice edges in the Belcher Islands, Nunavut, Canada. Arctic 53:61-68.

Gunn, A., G. Arlooktoo, and D. Kaomayok. 1988. The contribution of ecological knowledge of Inuit to wildlife management in the Northwest Territories. Pages 22-30 in M. M. R. Freeman and L. N. Carbyn, editors. Traditional knowledge and renewable resource management in northern regions. IUCN Commission on Ecology and the Boreal Institute for Northern Studies, Occasional Publication Number 23, Edmonton, Alberta, Canada.

Haney, J. C., and S. D. MacDonald. 1995. Ivory Gull, Pagophila eburnea. In A. Poole and F. Gill, editors. Birds of North America. Number 175. Birds of North America, Philadelphia, Pennsylvania, USA.

Hansen, K. 2002. A farewell to Greenland's wildlife. Gads Forlag, Copenhagen, Denmark.

Hay, K. 2000. Final report of the Inuit bowhead knowledge study. Nunavut Wildlife Management Board, Iqaluit, Nunavut, Northwest Territories, Canada.

Huntington, H. P. 2000. Using traditional ecological knowledge in science: methods and applications. Ecological Applications 10:1270-1274.

Huntington, H. P., T. V. Callaghan, S. F. Gearheard, and I. Krupnik. 2004. Matching traditional and scientific observations to detect environmental change: a discussion on arctic terrestrial ecosystems. Ambio Special Report 13:18-23.

Johannes, R. E. 1989. Traditional ecological knowledge: a collection of essays. World Conservation Union (IUCN), Gland, Switzerland.

Johannes, R. E. 1998. The case for data-less marine resource management: examples from tropical nearshore fisheries. Trends in Ecology and Evolution 13:243-246. 
Jonsson, J. 2001. Eider and eider husbandry in Iceland. Eider-Farmers Association, Mal og Mynd, Reykjavik, Iceland. [In Icelandic.]

Kampp, K. 1988. Migration and winter ranges of Brünnich's Guillemots Uria lomvia breeding or occurring in Greenland. Dansk Ornitologisk Forenings Tidsskrift 82:117-130.

Kampp, K., D. N. Nettleship, and P. G. H. Evans. 1994. Thick-billed Murres of Greenland: status and prospects. Pages 133-154 in D. N. Nettleship, J. Burger, and M. Gochfeld, editors. Seabirds on islands: threats, case-studies and actional plans. Birdlife International, Cambridge, UK.

Krech, S. III. 1999. The ecological Indian. W. W. Norton, New York, New York, USA.

Krupnik, I., and D. Jolly, editors. 2002. The earth is faster now: indigenous observations of Arctic environmental change. Arctic Research Consortium of the United States, Fairbanks, Alaska, USA.

Lebreton, J.-D., K. P. Burnham, J. Clobert, and D. R. Anderson. 1992. Modeling survival and testing biological hypotheses using marked animals: a unified approach with case studies. Ecological Monographs 62:67-118.

Ludwig, D., R. Hilborn, and C. Walters. 1993. Uncertainty, resource exploitation and conservation: lessons from history. Science 260:17-20.

MacDonald, S. D., and A. H. Macpherson. 1962. Breeding places of the ivory gull in arctic Canada. National Museum of Canada Bulletin Number 183, Biological Series 68:111-117.

Mallory, M. L., and A. J. Fontaine. 2004. Key marine habitat sites for migratory birds in Nunavut and the Northwest Territories. Canadian Wildlife Service Occasional Paper Number 110. Environment Canada, Ottawa, Ontario, Canada.

Mallory, M. L., A. J. Fontaine, and J. Akearok. 2003a. Status of the harlequin duck (Histrionicus histrionicus) on Baffin Island, Nunavut, Canada. Wildfowl 54:121-128.

Mallory, M. L., H. G. Gilchrist, A. J. Fontaine, and J. A. Akearok. 2003b. Local knowledge of Ivory Gull declines in Arctic Canada. Arctic
56:293-298.

Mauro, F., and P. D. Hardison. 2000. Traditional knowledge of indigenous and local communities: international debate and policy initiatives. Ecological Applications 10:1263-1269.

Nadasdy, P. 1999. The politics of TEK: power and the "integration" of knowledge. Arctic Anthropology 36: $1-18$.

Nadasdy, P. 2003. Reevaluating the comanagement success story. Arctic 56:367-380.

Nakashima, D. J., and D. J. Murray. 1988. The common eider (Somateria mollissima sedentaria) of eastern Hudson Bay: a survey of nest colonies and Inuit ecological knowledge. Environmental Studies Revolving Fund Report Number 102. Environment Canada, Ottawa, Ontario, Canada.

Orr, C. D., and J. L. Parsons. 1982. Ivory gulls, Pagophila eburnea, and ice edges in Davis Strait and the Labrador Sea. Canadian Field-Naturalist 96:323-328.

Pierotti, R., and D. Wildcat. 2000. Commentary: Traditional ecological knowledge: the third alternative. Ecological Applications 10:1333-1340.

Robertson, G. J., and H. G. Gilchrist. 1998. Evidence of population declines among common eiders breeding in the Belcher Islands, Northwest Territories. Arctic 51:378-385.

Robertson, G. J., and R. I. Goudie. 1999. Harlequin Duck, Histrionicus histrionicus. In A. Poole and F. Gill, editors. Birds of North America Number 466. Birds of North America, Philadelphia, Pennsylvania, USA.

Rydahl, K., and I. Egede, editors. 1999. Seminar om de levende ressourcer. Greenland Institute of Natural Resources, Nuuk, Technical Report Number 20 139:108-116.

Soper, J. D. 1946. Ornithological results of the Baffin Island expeditions of 1928-1929 and 1930-1931, together with more recent records. Auk 63:1-24.

Stenhouse, I., H. G. Gilchrist, M. J. Mallory, and G. J. Robertson. 2004. Status report on Ivory Gull, Pagophila eburnea. Committee on the Status of 
Endangered Wildlife in Canada. Environment Canada, Ottawa, Ontario, Canada.

UNEP (United Nations Environment Program). 1992. Convention on biological diversity. UNEP Number 92-8314. United Nations Environment Program, Nairobi, Kenya.

Van de Velde, F., I. Stirling, and E. Richardson. 2003. Polar bear (Ursus maritimus) denning in the area of the Simpson Peninsula, Nunavut.Arctic 56:191-197.

Walters, C. J., and R. Hilborn. 1978. Ecological optimization and adaptive management. Annual Review of Ecology and Systematics 9:157-188.

Walters, C. J., and C.S. Holling. 1990. Large-scale management experiments and learning by doing. Ecology 71:2060-2068.

Wilhere, G. F. 2002. Adaptive management in habitat conservation plans. Conservation Biology 16:20-29.

Zabel, C. J., L. M. Roberts, B. S. Mulder, H. B. Stauffer, J. R. Dunk, K. Wolcott, D. Solis, M. Gertsch, B. Woodbridge, A. Wright, G. Goldsmith, and C. Keckler. 2002. A collaborative approach in adaptive management at a largelandscape scale. Pages 241-253 in J. M. Stott, P. J. Heglund, M. L. Morrison, J. B. Haufler, M. G. Raphael, W. A. Wall, and F. B. Samson, editors. Predicting species occurrence: issues of accuracy and scale. Island Press, Washington, D.C., USA. 